\title{
Group A Rotavirus Associated with Encephalitis in Red Fox
}

\section{Chiara Busi, Vito Martella, Alice Papetti, Cristiano Sabelli, Davide Lelli, G. Loris Alborali, Lucia Gibelli, Daniela Gelmetti, Antonio Lavazza, Paolo Cordioli, ${ }^{1}$ M. Beatrice Boniotti}

In 2011, a group A rotavirus was isolated from the brain of a fox with encephalitis and neurologic signs, detected by rabies surveillance in Italy. Intracerebral inoculation of fox brain homogenates into mice was fatal. Genome sequencing revealed a heterologous rotavirus of avian origin, which could provide a model for investigating rotavirus neurovirulence.

G roup A rotaviruses are a major cause of diarrhea in hu$\mathbf{J}_{\text {mans and animals. Although group A rotaviruses infect }}$ particular species preferentially (homologous infection), they less frequently affect other species of mammals (heterologous infection), naturally and experimentally (1). In addition, there is evidence, albeit rare, that transmission of group A rotaviruses may occur between species of mammals and birds under natural and experimental conditions (2-4).

Group A rotaviruses have limited tissue tropism; infection is primarily restricted to cells of the small intestine. However, heterologous infection of mice with the rhesus group A rotavirus strain MMU 18006 was associated with extramucosal spread and hepatitis, but infections with bovine group A rotavirus $\mathrm{WC} 3$ and the homologous murine group A rotavirus EDIM were not (5), suggesting that some group A rotavirus strains may have unique or unexpected biological properties. In humans, group A rotavirus infection has been associated with acute encephalitis, although this association is based only on observational findings (6-9).

We detected a group A rotavirus strain in the brain of a fox with neurologic disorders. To determine the derivation of the virus, we further examined its genomic and biological features.

\section{The Study}

In 2011, as part of Italy's national surveillance program for rabies in wildlife, an adult red fox (Vulpes vulpes) with

Author affiliations: Istituto Zooprofilattico Sperimentale della Lombardia e dell'Emilia Romagna "Bruno Ubertini," Brescia, Italy (C. Busi, A. Papetti, C. Sabelli, D. Lelli, G.L. Alborali, L. Gibelli, D. Gelmetti, A. Lavazza, P. Cordioli, M.B. Boniotti); Università degli Studi di Bari, Bari, Italy (V. Martella)

DOI: https://doi.org/10.3201/eid2309.170158 neurologic signs was captured. Because its general condition worsened, the animal was euthanized and screened for a panel of neuropathogens (online Technical Appendix, https:// wwwnc.cdc.gov/EID/article/23/9/17-0158-Techapp1.pdf). Test results indicated that the animal was negative for rabies, canine distemper, Aujeszky's disease, leishmaniasis, and flavivirus infection (online Technical Appendix). Following the standard diagnostic procedures for rabies, we inoculated brain homogenate from the fox intracerebrally into suckling and weanling mice. The suckling mice died after 3-4 days and the weanling mice after 5 days. However, immunofluorescence testing of the brains of all mice, using rabies-specific hyperimmune serum, produced negative results (data not shown).

Use of negative-staining electron microscopy revealed rotavirus-like virions in the fox and mouse brains (Figure 1, panels A, B). Histologically, several alterations/ lesions, suggestive of acute inflammation, were observed in the cerebral cortex of the fox. Histologic analysis of gray matter revealed nonsuppurative encephalitis characterized by multifocal perivascular cuffing of lymphocytes, macrophages, and a few plasma cells as well as presence of multifocal small glial nodules. Perivascular accumulations varied from 1-cell thickness to thin cell accumulations (Figure 1, panel C). Neutrophils were observed within the lumen of some blood vessels and scattered in the gray matter. Neuronal necrosis and satellitosis were also present. By immunohistochemistry performed with a polyclonal serum raised against group A rotavirus, rotavirus antigen was detected in the cytoplasm of neurons, in dendrites, and in glial cells within inflamed areas of the brain (Figure 1, panel D).

An isolate, hereafter called fox-288356, was made from homogenates of the fox brain and from the brains of inoculated suckling and weanling mice, by using confluent monolayers of Marc-145 cells with and without trypsin. Cytopathic effect was characterized by foci of rounded cells, which tended to aggregate linearly on the surface of the monolayer and were clearly visible after 2 days (Figure 1, panel E). Electron microscopic observation identified rotavirus-like particles in the cell cryolysates (data not shown). The electropherotype of the cultured virus revealed a segmented genome characterized by a 5-1-3-2 profile with co-migration of segments 10 and 11 (online Technical Appendix Figure 1).

${ }^{1}$ Deceased. 


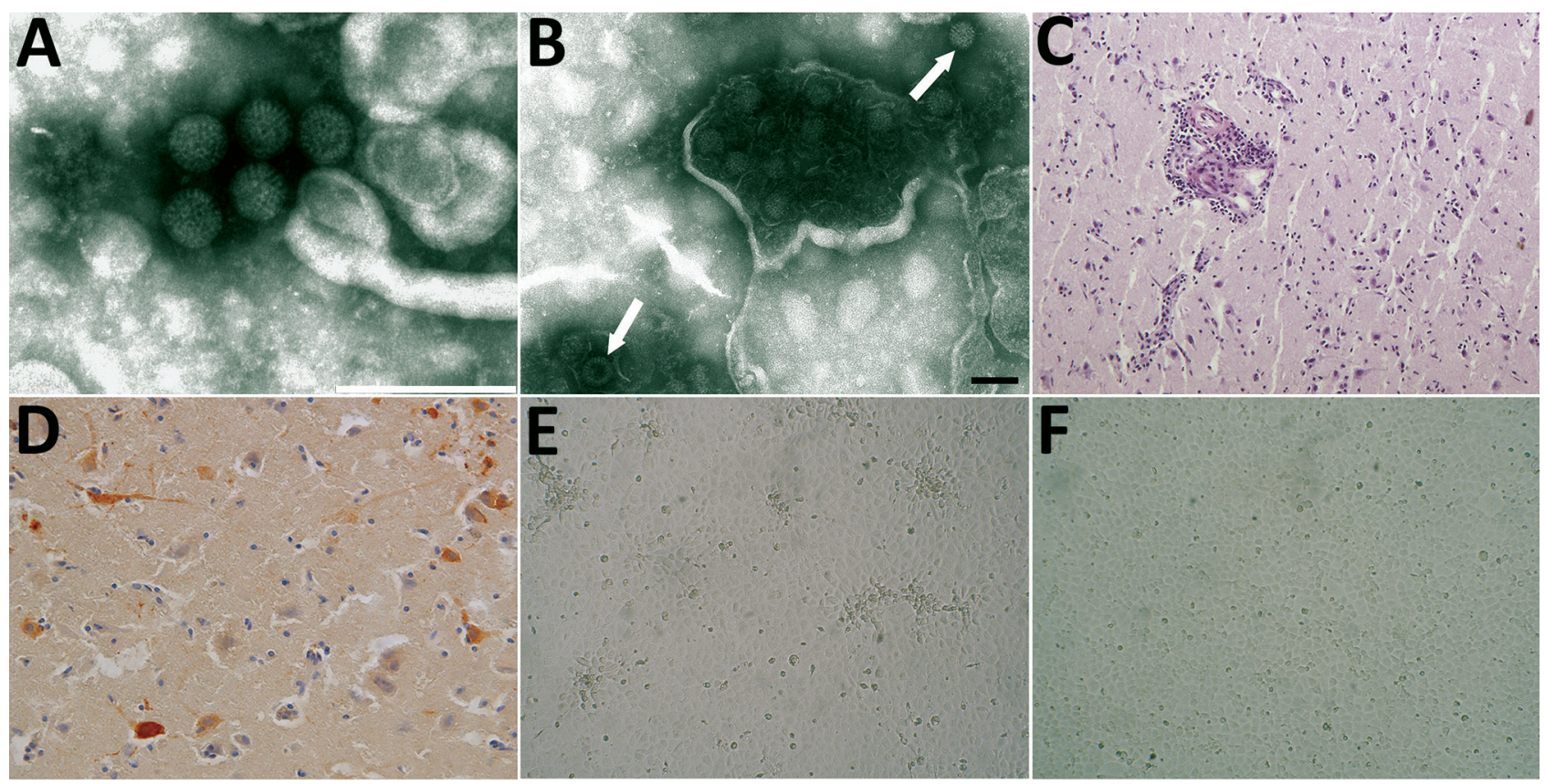

Figure 1. Images of brain of fox with group A rotavirus infection and brains of suckling and weanling mice inoculated with fox brain homogenates. A, B) Negative-staining electron microscopy. Presence of virions morphologically related to family Reoviridae from fox (A) and mouse (B) brain (arrows). Scale bar in panel A indicates $200 \mathrm{~nm}$; in panel B, $100 \mathrm{~nm}$. C, D) Histologic and immunohistochemical appearance of the cerebral cortex of the fox. C) Perivascular cuffing of inflammatory cells in the brain stained by hematoxylin and eosin (original magnification $\times 10$ ). D) Viral antigen in the cytoplasm of neurons (immunohistochemistry, original magnification $\times 20$ ). E) Foci with rounding cells of the confluent monolayers of Marc-145 cells infected with the brain homogenate from mouse at 2 days after inoculation (original magnification $\times 40$ ). F) Mock cells (original magnification $\times 40$ ).

The genome of fox-288356 was 18,849 nt and showed high sequence homology to avian strain PO-13, isolated from a pigeon $(2,4)$. Homology was apparent in most genome segments $(89 \%-94 \%$ nt and $91 \%-98 \%$ aa), except for the ninth segment, coding for viral protein (VP) 7 (86\% nt and $88 \%$ aa), and the tenth segment, coding for nonstructural protein (NSP) 4 (79\% nt and $83 \%$ aa) (Table 1). After phylogenetic analysis of the concatenated genome (Figure 2) and individual genome segments (online Technical Appendix Figure 3), fox-288356 grouped with avian group A rotaviruses. The genomic constellation of fox-288356 was G18P[17]-R4-C4-M4-A4-I4-T4-N4-E19-H4 (Table 2).
Several amino acid mutations were present in the major antigenic regions (A, B, and C) of VP7 (online Technical Appendix Figure 4) and in key residues of VP4 (online Technical Appendix Figure 5). VP4 contained only 1 of the 3 arginine residues required for trypsin-mediated cleavage into the VP8* and VP5* subunits (10). This finding seems consistent with the ability of fox-288356 to grow in cell cultures in the absence of trypsin, a feature that has been observed for some avian group A rotaviruses (11).

We classified the NSP4 of fox-288356 as a novel E genotype, E19, as indicated by the Rotavirus Classification Working Group. We also found differences between the

\begin{tabular}{|c|c|c|c|c|}
\hline \multirow{2}{*}{$\begin{array}{l}\text { Segment number/encoded } \\
\text { protein }\end{array}$} & \multicolumn{2}{|c|}{ Nucleotide/amino acid length (genotype) } & \multirow{2}{*}{$\begin{array}{c}\% \text { Nucleotide sequence } \\
\text { identity }\end{array}$} & \multirow{2}{*}{$\begin{array}{c}\% \text { Amino acid } \\
\text { sequence identity }\end{array}$} \\
\hline & Fox-288356† & $\mathrm{PO}-13 \ddagger$ & & \\
\hline 1/VP1 & $3,305 / 1,089(\mathrm{R} 4)$ & $3,302 / 1,088(\mathrm{R} 4)$ & 93 & 98 \\
\hline 2/VP2 & $2,738 / 897(\mathrm{C} 4)$ & $2,738 / 897(\mathrm{C} 4)$ & 91 & 97 \\
\hline 3/VP3 & $2,583 / 829$ (M4) & $2,583 / 829$ (M4) & 91 & 94 \\
\hline 4/VP4 & $2,349 / 770(P[17])$ & $2,349 / 770(P[17])$ & 92) & 95 \\
\hline 5/NSP1 & $1,871 / 576(\mathrm{~A} 4)$ & $1,870 / 576(\mathrm{~A} 4)$ & 86 & 91 \\
\hline 6/VP6 & $1,348 / 397(14)$ & $1,348 / 397(14)$ & 94 & 98 \\
\hline 7/NSP3 & 1,092/306 (T4) & 1,092/306 (T4) & 89 & 95 \\
\hline 8/NSP2 & $1,043 / 315(A 4)$ & $1,042 / 315(\mathrm{~N} 4)$ & 93 & 95 \\
\hline 9/VP7 & $1,065 / 329$ (G18) & $1,065 / 329(\mathrm{G} 18)$ & 86 & 88 \\
\hline 10/NSP4 & $726 / 169$ (E19) & $727 / 169(\mathrm{E} 4)$ & 77 & 83 \\
\hline 11/NSP5 & $729 / 218(\mathrm{H} 4)^{\prime}$ & $729 / 218(\mathrm{H} 4)$ & 93 & 90 \\
\hline
\end{tabular}

${ }^{*} \mathrm{NSP}$, nonstructural protein; VP, viral protein

†Rotavirus isolated from a red fox.

$\ddagger$ Rotavirus isolated from a pigeon. 


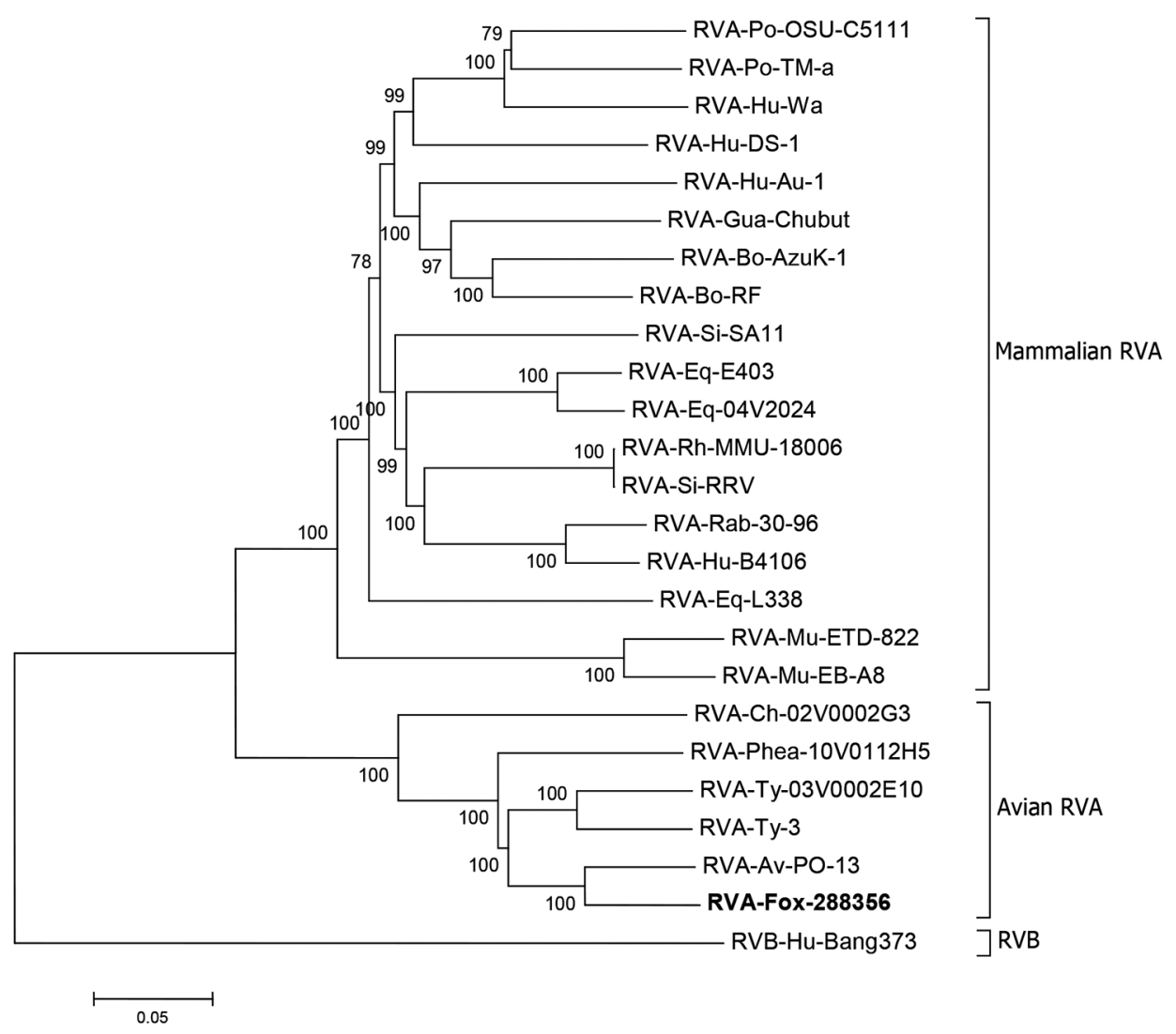

Figure 2. Phylogenetic analysis of RVA strain fox-288356.

Analysis was performed on the basis of the concatenated nucleotide sequences of genomic segments. Fox-288356 is correlated with RVAPO-13 (from pigeon) and clustered with the avian RVA. Reference sequences are identified by strain name and GenBank accession number. Scale bar indicates nucleotide substitutions per site. RVA, group A rotavirus; $\mathrm{RVB}$, group $\mathrm{B}$ rotavirus.
NSP4 of fox-288356 and other group A rotaviruses (online Technical Appendix Figure 6).

\section{Conclusion}

Although in humans group A rotaviruses are mainly associated with gastroenteritis, the literature indicates that group A rotaviruses may also be associated with acute encephalitis or encephalopathy (6-9). This correlation has been supposed for children in whom neurologic signs develop concomitantly or shortly after acute gastroenteritis caused by group A rotavirus $(7,9)$ and after detection of group A rotavirus RNA in the cerebrospinal fluid of patients with neurologic signs $(6,8)$. It remains unclear whether systemic spread of group A rotavirus and localization in the central nervous system is the result of host-related factors, whether it depends on intrinsic biological features of group A rotavirus strains, or whether it eventually results from a combination of both elements. Fox-288356 was probably responsible for the neurologic disease observed in the fox, as suggested by the results of our diagnostic investigations and by the inflammatory lesions in the brain of the animal.

Genomic characterization indicated that fox-288356 shared the same genetic backbone as avian strain PO-13 and avian-like bovine strain 993-83 (2). Under experimental conditions, oral inoculation of mice with pigeon group A rotavirus strain $\mathrm{PO}-13$ infected and caused diarrhea in the mice, but inoculation with turkey group A rotavirus strain Tyr-1 did not (4). Also, the synthetic NSP4 toxic peptide of strain PO-13 elicited diarrhea in suckling mice (12). It is tempting to speculate that some avian group A rotaviruses (e.g., group A rotaviruses with the PO-13

\begin{tabular}{|c|c|c|c|c|c|c|c|c|c|c|c|}
\hline Group A rotavirus strain & VP7 & VP4 & VP6 & VP1 & VP2 & VP3 & NSP1 & NSP2 & NSP3 & NSP4 & NSP5 \\
\hline Fox-wt/ITA/288356/2011/G18P[17] & G18 & $\mathrm{P}[17]$ & 14 & R4 & C4 & M4 & A4 & N4 & T4 & E19 & $\mathrm{H} 4$ \\
\hline Pigeon-tc/JPN/PO-13/1983/G18P[17] & G18 & $\mathrm{P}[17]$ & 14 & R4 & C4 & M4 & A4 & N4 & T4 & E4 & $\mathrm{H} 4$ \\
\hline Bovine-wt/GER/993_83/1983/G18P[17] & G18 & $\mathrm{P}[17]$ & 14 & & & & & & & & \\
\hline Turkey-tc/GER/03V0002E10/2003/G22P[35] & G22 & $\mathrm{P}[35]$ & 14 & R4 & C4 & M4 & A16 & N4 & T4 & E11 & $\mathrm{H} 4$ \\
\hline Group A rotavirus/tTurkey-tc/IRL/Ty-3/1979/G7P[35] & G7 & $\mathrm{P}[35]$ & 14 & R4 & C4 & M4 & A16 & N4 & T4 & E11 & $\mathrm{H} 14$ \\
\hline Group A rotavirus/Turkey-tc/IRL/Ty-1/1979/G17P[38] & G17 & $\mathrm{P}[38]$ & 14 & R4 & C4 & M4 & A16 & N4 & T4 & E4 & $\mathrm{H} 4$ \\
\hline Pheasant-tc/GER/10V0112H5/2010/G23P[37] & G23 & $\mathrm{P}[37]$ & 14 & R4 & $\mathrm{C} 4$ & M4 & A16 & N10 & T4 & E4 & $\mathrm{H} 4$ \\
\hline Chicken-tc/GER/02V0002G3/2002/G19P[30] & G19 & $\mathrm{P}[30]$ & $\mathrm{I} 11$ & R6 & C6 & M7 & A16 & N6 & T8 & E10 & $\mathrm{H} 8$ \\
\hline
\end{tabular}

${ }^{*}$ Gray shading indicates homology. NSP, nonstructural protein; VP, viral protein. 
genome backbone) have the ability to cross the host-species barrier more easily than other avian group A rotaviruses (Table 1). Another bovine group A rotavirus strain, N2342, with a VP4 gene related to the avian strain PO-13, has been recently identified in Japan (3).

The virus isolated from the fox displayed a unique NSP4, which was proposed as a novel genotype, E19. NSP4 serves as an intracellular receptor for immature particles and interacts with viral capsid proteins during viral morphogenesis (13). NSP4 also acts as a viral enterotoxin $(13,14)$, and the enterotoxic activity has been mapped to a region, the toxic peptide, spanning amino acids $114-135$ of NSP4 (14). Changes in residues within the NSP4 toxic peptide have been associated with alterations in the toxigenic activity of NSP4 and in rotavirus virulence (15).

The detection of fox-288356 in the brain of a fox supports the accumulating clinical evidence for the association between group A rotaviruses and neurologic signs in human patients. Whether some group A rotavirus strains intrinsically possess the ability to spread to the central nervous system, thereby causing neurologic disease, remains to be explored.

\section{Acknowledgments}

We thank Chiara Garbarino, Anna Tirelli, and Giuseppe

Bertocchi for their technical support and Krisztian Banyai for his critical revision of the manuscript.

Dr. Busi is a scientist at the Istituto Zooprofilattico Sperimentale della Lombardia e Emilia Romagna. Her primary research interests include molecular diagnosis and epidemiology of viral and bacterial infectious diseases.

\section{References}

1. Martella V, Bányai K, Matthijnssens J, Buonavoglia C, Ciarlet M. Zoonotic aspects of rotaviruses. Vet Microbiol. 2010;140:246-55. http://dx.doi.org/10.1016/j.vetmic.2009.08.028

2. Rohwedder A, Schütz KI, Minamoto N, Brüssow H. Sequence analysis of pigeon, turkey, and chicken rotavirus VP8* identifies rotavirus $993 / 83$, isolated from calf feces, as a pigeon rotavirus. Virology. 1995;210:231-5. http://dx.doi.org/10.1006/ viro.1995.1338

3. Mitake H, Ito N, Okadera K, Okada K, Nakagawa K, Tanaka T, et al. Detection of avian-like rotavirus A VP4 from a calf in Japan. J Vet Med Sci. 2015;77:221-4. http://dx.doi.org/10.1292/ jvms.14-0379
4. Mori Y, Sugiyama M, Takayama M, Atoji Y, Masegi T, Minamoto N. Avian-to-mammal transmission of an avian rotavirus: analysis of its pathogenicity in a heterologous mouse model. Virology. 2001;288:63-70. http://dx.doi.org/10.1006/viro.2001.1051

5. Uhnoo I, Riepenhoff-Talty M, Dharakul T, Chegas P, Fisher JE, Greenberg HB, et al. Extramucosal spread and development of hepatitis in immunodeficient and normal mice infected with rhesus rotavirus. J Virol. 1990;64:361-8.

6. Dickey M, Jamison L, Michaud L, Care M, Bernstein DI, Staat MA. Rotavirus meningoencephalitis in a previously healthy child and a review of the literature. Pediatr Infect Dis J. 2009;28:318-21. http://dx.doi.org/10.1097/INF.0b013e31818ddbe9

7. Kobayashi S, Negishi Y, Ando N, Ito T, Nakano M, Togari H, et al. Two patients with acute rotavirus encephalitis associated with cerebellar signs and symptoms. Eur J Pediatr. 2010;169:1287-91. http://dx.doi.org/10.1007/s00431-010-1202-y

8. Arakawa C, Fujita Y, Imai Y, Ishii W, Kohira R, Fuchigami T, et al. Detection of group A rotavirus RNA and antigens in serum and cerebrospinal fluid from two children with clinically mild encephalopathy with a reversible splenial lesion. Jpn J Infect Dis. 2011;64:204-7.

9. Rath BA, Gentsch J, Seckinger J, Ward K, Deputy S. Rotavirus encephalitis with basal ganglia involvement in an 8-month-old infant. Clin Pediatr (Phila). 2013;52:260-4. http://dx.doi.org/10.1177/0009922811417301

10. Trask SD, Wetzel JD, Dermody TS, Patton JT. Mutations in the rotavirus spike protein VP4 reduce trypsin sensitivity but not viral spread. J Gen Virol. 2013;94:1296-300. 10.1099/vir.0.050674-0 http://dx.doi.org/10.1099/vir.0.050674-0

11. McNulty MS, Allan GM, Todd D, McFerran JB, McKillop ER, Collins DS, et al. Isolation of rotaviruses from turkeys and chickens: demonstration of distinct serotypes and RNA electropherotypes. Avian Pathol. 1980;9:363-75. http://dx.doi.org/10.1080/03079458008418420

12. Mori Y, Borgan MA, Ito N, Sugiyama M, Minamoto N. Diarrheainducing activity of avian rotavirus NSP4 glycoproteins, which differ greatly from mammalian rotavirus NSP4 glycoproteins in deduced amino acid sequence in suckling mice. J Virol. 2002;76:5829-34. http://dx.doi.org/10.1128/JVI.76.11.5829-5834.2002

13. Ramig RF. Pathogenesis of intestinal and systemic rotavirus infection. J Virol. 2004;78:10213-20. http://dx.doi.org/10.1128/ JVI.78.19.10213-10220.2004

14. Lorrot M, Vasseur M. How do the rotavirus NSP4 and bacterial enterotoxins lead differently to diarrhea? Virol J. 2007;4:31. http://dx.doi.org/10.1186/1743-422X-4-31

15. Zhang M, Zeng CQ, Dong Y, Ball JM, Saif LJ, Morris AP, et al. Mutations in rotavirus nonstructural glycoprotein NSP4 are associated with altered virus virulence. J Virol. 1998;72:3666-72.

Address for correspondence: M. Beatrice Boniotti, Research and Development Laboratory, Istituto Zooprofilattico Sperimentale della Lombardia e Emilia Romagna, via Bianchi 9, 25124 Brescia (BS), Italy; email: mariabeatrice.boniotti@izsler.it 